\title{
PENGARUH PENGGUNAAN PERANGKAT PEMBELAJARAN IPA TERPADU TIPE CONNECTED TERHADAP KOMPETENSI PENGETAHUAN DAN KETERAMPILAN SISWA SMP NEGERI 2 KELUMPANG TENGAH
}

\author{
Ristati Ningsih $^{1)}$ Endang Susantini $^{2)}$, Bambang Sugiarto ${ }^{3)}$ \\ ${ }^{1)}$ Program Studi Pendidikan Sains, Program Pascasarjana, Universitas Negeri Surabaya \\ ${ }^{2)}$ Dosen Program Studi Pendidikan Sains, Pascasarjana, Universitas Negeri Surabaya \\ ${ }^{3)}$ Dosen Jurusan Kimia FMIPA Universitas Negeri Surabaya \\ e-mail: thatiec@gmail.com
}

\begin{abstract}
Abstrak: Penelitian ini bertujuan untuk mengetahui pengaruh penggunaan perangkat pembelajaran IPA Terpadu tipe connected terhadap kompetensi pengetahuan dan keterampilan siswa SMP Negeri 2 Kelumpang Tengah. Rancangan yang digunakan dalam penelitian ini yaitu one-group pretest-posttest design dengan menggunakan satu kelompok subjek yaitu siswa kelas VII-B SMP Negeri 2 Kelumpang Tengah sebanyak 24 siswa. Teknik pengumpulan data menggunakan tes dan observasi. Teknik analisis data menggunakan analisis deskriptif kualitatif dan kuantitatif. Hasil analisis data penelitian menunjukkan bahwa pembelajaran menggunakan perangkat pembelajaran IPA Terpadu tipe connected berpengaruh terhadap hasil belajar siswa dalam: (1) meningkatkan kompetensi pengetahuan siswa dengan skor $\mathrm{N}$-Gain berkategori tinggi; dan (2) mencapai ketuntasan indikator kompetensi keterampilan siswa yaitu dengan rata-rata kelas sebesar 89 atau berkategori sangat baik. Berdasarkan hasil penelitian ini, dapat disimpulkan bahwa penggunaan perangkat pembelajaran IPA Terpadu tipe connected dapat meningkatkan kompetensi pengetahuan dan mencapai ketuntasan indikator kompetensi keterampilan siswa SMP Negeri 2 Kelumpang Tengah.
\end{abstract}

Kata Kunci: Tipe Connected, Kompetensi Pengetahuan, Kompetensi Keterampilan

\begin{abstract}
The purpose of this research is to determine the effect of the use of integrated science learning materials type connected to the competence of the knowledge and skills of students of SMP Negeri 2 Kelumpang Tengah. The design used in this study is a one-group pretest-posttest design using a single group of subjects that students of class VII-B SMP Negeri 2 Kelumpang Tengah as many as 24 students. Data collection technique used tests and observation. Data were analyzed using descriptive analysis of qualitative and quantitative. The results of the analysis of research data shows that learning to use the materials type connected integrated science teaching effect on student learning outcomes in: (1) improve the competence of students' knowledge with a score of N-Gain high category; and (2) achieve mastery indicator of skill competencies that students with an average grade of 89 or excellent category. Based on these results, we can conclude that the use of the materials types connected integrated science teaching can improve and achieve mastery knowledge competence indicator of competence skills of students of SMP Negeri 2 Kelumpang Tengah.
\end{abstract}

Keywords: Connected Type, Knowledge Competencies, Skill Competecies

\section{PENDAHULUAN}

Pembaharuan kurikulum dalam dunia pendidikan merupakan suatu keniscayaan guna merespon tantangan perkembangan zaman. Begitupun yang terjadi di Indonesia, kurikulum telah mengalami pembaharuan berkali-kali, hingga yang diterapkan sekarang yang diberi nama kurikulum 2013. Kurikulum mempersiapkan peserta didik dalam menghadapi tantangan-tantangan di masa depan melalui pengetahuan, keterampilan, sikap dan keahlian untuk beradaptasi serta bisa bertahan hidup dalam lingkungan yang senantiasa berubah (Wibowo, 2014).

Kurikulum 2013 menekankan penerapan pendekatan ilmiah atau scientific approach pada proses pembelajaran. Pendekatan ilmiah (scientific approach) dalam pembelajaran sebagaimana dimaksud meliputi mengamati, menanya, mencoba, mengolah, menyajikan, menyimpulkan, dan mencipta untuk semua mata pelajaran (Sudarwan dalam Kemendikbud, 2013). Menurut McCollum dijelaskan bahwa komponen-komponen penting dalam mengajar 
menggunakan pendekatan saintifik diantaranya adalah guru harus menyajikan pembelajaran yang dapat meningkatkan rasa keingintahuan (Foster a sense of wonder), meningkatkan keterampilan mengamati (Encourage observation), melakukan analisis (Push for analysis) dan berkomunikasi (Require communication) (Wibowo, 2014).

Pembelajaran Ilmu Pengetahuan Alam (IPA) yang dilakukan di SMP seharusnya diberikan secara terpadu. Melalui pembelajaran IPA Terpadu, siswa dapat memperoleh pengalaman langsung, sehingga dapat menambah kekuatan untuk menerima, menyimpan, dan menerapkan konsep yang dipelajarinya. Putra, dkk (2013) menyatakan bahwa pembelajaran terpadu merupakan salah satu alternative untuk meningkatkan hasil belajar IPA. Hal tersebut sejalan dengan konsep penyajian materi IPA pada Kurikulum 2013, di mana pembelajaran IPA diintegrasikan melalui materi biologi, fisika, dan kimia (Permendikbud, 2014).

Dalam penelitian ini pengintegrasian yang digunakan dalam memadukan materi IPA di SMP tersebut adalah tipe connected, karena tipe connected digunakan untuk memadukan materi dalam satu disiplin ilmu (mata pelajaran). Dengan cara connected, pembelajaran dapat dilakukan pada materi bidang tertentu (misalnya kimia), kemudian materi bidang lain yang relevan ikut dibahas (Permendikbud, 2014). Materi-materi yang digabungkan dapat berupa materi-materi yang dirasa sulit dengan topik penghubung yang lebih sederhana serta mudah dipahami, yang dapat mengaitkan materi-materi tesebut. Salah satunya adalah materi asam basa dan pemisahan campuran yang dapat digabungkan dalam pengembangan materinya menggunakan model integrasi tipe connected. Penggabungan materinya dilakukan melalui topik "Pencemaran Air", yang dalam pembahasannya mencakup materi identifikasi sifat air yang tercemar (asam basa) dan materi penjernihan air yang tercemar (pemisahan campuran). Tipe connected ini diharapkan dapat memperkaya pengetahuan (knowledge) yang dimiliki siswa, serta pengaplikasian pengetahuan tersebut di kehidupan.

Beberapa penelitian menunjukkan bahwa model integrasi tipe connected efektif digunakan dalam pembelajaran. Antara lain penelitian yang dilakukan oleh Andansari (2015) yang menyatakan bahwa penerapan pembelajaran IPA Terpadu tipe connected meningkatkan hasil belajar siswa. Selain itu, Nisak (2013) dalam penelitiannya menyatakan bahwa model integrasi tipe connected dapat membantu siswa untuk mencapai ketuntasan indikator, yang dilihat dari analisis hasil belajar pada aspek kognitif produk dan kognitif proses. Hal ini terjadi karena dalam tipe connected, pembelajaran berpusat pada siswa.

Berdasarkan uraian latar belakang di atas, maka peneliti tertarik untuk melakukan penelitian tentang pengaruh penggunaan perangkat pembelajaran IPA Terpadu tipe connected terhadap kompetensi pengetahuan dan keterampilan siswa SMP Negeri 2 Kelumpang Tengah.

\section{METODE PENELITIAN}

Penelitian dilakukan pada awal bulan Oktober 2016. Siswa yang dijadikan subjek penelitian yaitu siswa kelas VII-B SMP Negeri 2 Kelumpang Tengah tahun pelajaran 2016/2017 sebanyak 24 siswa.

Teknik pengumpulan data menggunakan tes dan observasi. Rancangan yang dilakukan pada penelitian ini menggunakan one-group pretest-posttest design.

\section{A. Analisis hasil belajar kompetensi pengetahuan}

Siswa dikategorikan tuntas secara individual jika telah mencapai nilai KKM yaitu 65. Siswa tuntas secara klasikal jika kelas tersebut terdapat $\geq 85 \%$ siswa yang tuntas belajarnya (Depdiknas, 2006).

Peningkatan kompetensi pengetahuan siswa diukur menggunakan analisis $N$-Gain yang diadaptasi dari rumus $N$-Gain (Hake, 1999).

$$
<g>=\frac{<S_{\text {post }}>-<S_{\text {pre }}>}{100-<S_{\text {pre }}>}
$$

Keterangan:

$\langle\mathrm{g}\rangle \quad=$ Peningkatan hasil belajar (rata-rata $\mathrm{N}$ Gain)

$\left\langle\mathrm{S}_{\text {pre }}\right\rangle \quad=$ Rata-rata nilai pretest

$\left\langle\mathrm{S}_{\text {post }}\right\rangle=$ Rata-rata nilai posttest 
Perhitungan $N$-Gain kemudian dikonversi dengan menggunakan kriteria seperti yang ditunjukkan pada Tabel 1.

Tabel 1. Kriteria Normalized Gain

\begin{tabular}{|c|c|}
\hline Skor $(<\mathrm{g}>)$ & $\begin{array}{c}\text { Kriteria Normalized } \\
\text { Gain }\end{array}$ \\
\hline $0,70<(<\mathrm{g}>)$ & Tinggi \\
\hline $0,30 \leq(<g>) \leq$ & Sedang \\
0,70 & Rendah \\
\hline$(<\mathrm{g}>)<0,30$ & \\
\hline
\end{tabular}

\section{B. Analisis hasil belajar kompetensi \\ keterampilan}

Penilaian kompetensi keterampilan dilakukan dengan memberikan skor terhadap aspek kinerja siswa yang diamati berdasarkan rubrik penilaian keterampilan. Data kemudian dianalisis untuk memperoleh rata-rata skor siswa terhadap tiap indikator keterampilan kinerja, dan dideskripsikan menurut skala berikut:

$$
\begin{array}{ll}
1,00-1,75 & : \text { tidak baik } \\
1,76-2,50 & : \text { kurang baik } \\
2,51-3,25 & : \text { baik } \\
3,26-4,00 & : \text { sangat baik }
\end{array}
$$

Rata-rata skor keseluruhan indikator dikonversi untuk memperoleh nilai akhir keterampilan siswa dengan menggunakan angka pada skala 0-100 dan diberi predikat sesuai ketentuan (Dit. Pembinaan SMP, 2015):

$\begin{array}{ll}\text { Sangat Baik } & : \text { 86-100 } \\ \text { Baik } & : 71-85 \\ \text { Cukup } & : 56-70 \\ \text { Kurang } & : \leq 55\end{array}$

Hasil belajar kompetensi keterampilan dinyatakan tercapai apabila siswa memperoleh nilai rata-rata keterampilan > 70 atau minimal berkategori baik.

\section{HASIL DAN PEMBAHASAN}

\section{A. Hasil Belajar Kompetensi Pengetahuan}

Ketuntasan belajar siswa ditentukan dengan cara membandingkan nilai posttest dengan KKM yang ditetapkan di sekolah. SMP Negeri 2 Kelumpang Tengah menetapkan KKM mata pelajaran IPA untuk kelas VII yaitu 65. Hasil perhitungan ketuntasan belajar siswa dapat dilihat pada Tabel 2 berikut.
Tabel 2. Ketuntasan Belajar Aspek Pengetahuan

\begin{tabular}{|c|c|c|c|c|}
\hline No. & $\begin{array}{c}\text { Inisial } \\
\text { Siswa }\end{array}$ & $\begin{array}{c}\text { Jumlah } \\
\text { jawaban } \\
\text { benar }\end{array}$ & Skor & Ket. \\
\hline 1 & C1 & 14 & 78 & Tuntas \\
\hline 2 & C2 & 12 & 67 & Tuntas \\
\hline 3 & C3 & 16 & 89 & Tuntas \\
\hline 4 & C4 & 14 & 78 & Tuntas \\
\hline 5 & C5 & 17 & 94 & Tuntas \\
\hline 6 & C6 & 18 & 100 & Tuntas \\
\hline 7 & C7 & 15 & 83 & Tuntas \\
\hline 8 & C8 & 14 & 78 & Tuntas \\
\hline 9 & C9 & 14 & 78 & Tuntas \\
\hline 10 & C10 & 17 & 94 & Tuntas \\
\hline 11 & C11 & 15 & 83 & Tuntas \\
\hline 12 & C12 & 14 & 78 & Tuntas \\
\hline 13 & C13 & 18 & 100 & Tuntas \\
\hline 14 & C14 & 14 & 78 & Tuntas \\
\hline 15 & C15 & 16 & 89 & Tuntas \\
\hline 16 & C16 & 15 & 83 & Tuntas \\
\hline 17 & C17 & 13 & 72 & Tuntas \\
\hline 18 & C18 & 15 & 83 & Tuntas \\
\hline 19 & C19 & 14 & 78 & Tuntas \\
\hline 20 & C20 & 14 & 78 & Tuntas \\
\hline 21 & C21 & 17 & 94 & Tuntas \\
\hline 22 & C22 & 13 & 72 & Tuntas \\
\hline 23 & C23 & 17 & 94 & Tuntas \\
\hline 24 & C24 & 17 & 94 & Tuntas \\
\hline & Ketuntasan Klasikal & \multicolumn{1}{|c|}{$\mathbf{1 0 0} \%$} \\
\hline & & & & \\
\hline
\end{tabular}

Dapat dilihat pada Tabel 2 bahwa seluruh siswa telah melampaui nilai KKM, dengan skor terendah yang dicapai siswa yaitu 67 dan skor tertinggi 100 . Secara klasikal nilai siswa sudah mencapai ketuntasan dengan persentasi ketuntasan $100 \%$ (Depdiknas, 2006).

Ada atau tidaknya peningkatan hasil belajar pengetahuan siswa dapat diketahui dengan cara menghitung perbandingan nilai pretest dan posttest menggunakan analisis normalized gain ( $N$-Gain). Hasil perhitungan $\mathrm{N}$-Gain secara ringkas disajikan dalam Tabel 3 berikut.

Tabel 3. Peningkatan Hasil Belajar Aspek Pengetahuan

\begin{tabular}{|c|c|c|c|c|c|}
\hline \multirow{2}{*}{ No. } & \multirow{2}{*}{$\begin{array}{c}\text { Inisial } \\
\text { Siswa }\end{array}$} & \multicolumn{2}{|c|}{ Nilai } & \multirow{2}{*}{ N-Gain } & \multirow{2}{*}{ Kategori } \\
\cline { 3 - 4 } & & Pretest & Posttest & & \\
\hline \hline 1 & $\mathrm{C} 1$ & 33 & 78 & 0.64 & Sedang \\
\hline 2 & $\mathrm{C} 2$ & 33 & 67 & 0.54 & Sedang \\
\hline
\end{tabular}




\begin{tabular}{|c|c|c|c|c|c|}
\hline \multirow{2}{*}{ No. } & \multirow{2}{*}{$\begin{array}{l}\text { Inisial } \\
\text { Siswa }\end{array}$} & \multicolumn{2}{|c|}{ Nilai } & \multirow{2}{*}{$N$-Gain } & \multirow{2}{*}{ Kategori } \\
\hline & & Pretest & Posttest & & \\
\hline 3 & $\overline{\mathrm{C} 3}$ & 22 & 89 & 0.75 & Tinggi \\
\hline 4 & $\mathrm{C} 4$ & 33 & 78 & 0.62 & Sedang \\
\hline 5 & $\mathrm{C} 5$ & 33 & 94 & 0.92 & Tinggi \\
\hline 6 & C6 & 44 & 100 & 0.92 & Tinggi \\
\hline 7 & C7 & 28 & 83 & 0.73 & Tinggi \\
\hline 8 & $\mathrm{C} 8$ & 28 & 78 & 0.64 & Sedang \\
\hline 9 & C9 & 33 & 78 & 0.62 & Sedang \\
\hline 10 & C10 & 33 & 94 & 0.92 & Tinggi \\
\hline 11 & C11 & 28 & 83 & 0.79 & Tinggi \\
\hline 12 & $\mathrm{C} 12$ & 33 & 78 & 0.64 & Sedang \\
\hline 13 & $\mathrm{C} 13$ & 56 & 100 & 1.00 & Tinggi \\
\hline 14 & C14 & 22 & 78 & 0.71 & Tinggi \\
\hline 15 & $\mathrm{C} 15$ & 39 & 89 & 0.77 & Tinggi \\
\hline 16 & C16 & 28 & 83 & 0.71 & Tinggi \\
\hline 17 & $\mathrm{C} 17$ & 33 & 72 & 0.62 & Sedang \\
\hline 18 & $\mathrm{C} 18$ & 28 & 83 & 0.73 & Tinggi \\
\hline 19 & C19 & 33 & 78 & 0.69 & Sedang \\
\hline 20 & $\mathrm{C} 20$ & 22 & 78 & 0.71 & Tinggi \\
\hline 21 & $\mathrm{C} 21$ & 39 & 94 & 0.92 & Tinggi \\
\hline 22 & $\mathrm{C} 22$ & 33 & 72 & 0.62 & Sedang \\
\hline 23 & $\mathrm{C} 23$ & 28 & 94 & 0.93 & Tinggi \\
\hline 24 & $\mathrm{C} 24$ & 28 & 94 & 0.92 & Tinggi \\
\hline \multicolumn{5}{|c|}{ Modu } & Tinggi \\
\hline
\end{tabular}

Modus dari kategori $\mathrm{N}$-Gain seperti terlihat pada Tabel 3 di atas adalah berkategori tinggi, sehingga dapat disimpulkan bahwa terdapat peningkatan hasil belajar pengetahuan siswa dengan kategori tinggi $(N$-gain $>0,70)$.

Penerapan pembelajaran dengan menggunakan perangkat pembelajaran IPA Terpadu tipe connected efektif meningkatkan hasil belajar siswa. Eggen dan Kauchak mengemukakan bahwa pembelajaran efektif terjadi bila siswa dilibatkan secara aktif dalam mengorganisasi dan menemukan hubungan dari informasi yang yang diberikan, tidak hanya secara pasif menerima pengetahuan dari guru. Hal itu sesuai dengan perangkat pembelajaran tipe connected yang dikembangkan karena menggunakan pendekatan ilmiah yang mengharuskan siswa aktif. Sejalan dengan teori konstruktivis, yang menyatakan bahwa guru dapat membangun situasi-situasi yang memungkinkan siswa terlibat secara aktif melalui pengolahan-pengolahan materi dan interaksi sosial (Schunk, 2012).

Adanya variasi berbagai metode yang digunakan dalam pembelajaran, yaitu demonstrasi, eksperimen, pengamatan, tanya jawab, dan diskusi, juga membuat pembelajaran yang dilakukan juga memberikan pengalaman yang berarti bagi siswa. Slameto (2010) menyatakan bahwa variasi metode pembelajaran yang dilakukan membuat penyajian bahan pelajaran lebih menarik perhatian siswa, mudah diterima siswa, dan kelas juga lebih hidup.

Pembelajaran IPA yang disajikan secara terpadu bersifat luwes (fleksibel) (Hamdayama, 2014). Hal ini karena guru bisa mengaitkan berbagai materi yang saling terkait baik dalam satu mata pelajaran (connected), atau pun antar bidang studi (model integrasi materi lainnya). Adanya pengintegrasian materi-materi ini membuat siswa memiliki pengetahuan yang terintegrasi (tidak terpisah-pisah). Siswa memperoleh gambaran bahwa diantara ilmuilmu pengetahuan saling berhubungan dan saling melengkapi (Slameto, 2010).

Adanya pengalaman fisik baru yang dialami siswa dan manipulasi lingkungan, yaitu pengalaman belajar yang berbeda dari pengalaman belajar siswa sebelumnya, membuat kegiatan belajar mengajar yang dilakukan menjadi lebih bermakna. Sejalan dengan teori yang dikemukakan oleh Piaget bahwa pengalaman fisik dan manipulasi lingkungan sangat berperan penting agar terjadi perubahan perkembangan pada siswa (Slavin, 2011).

Saat pembelajaran guru juga selalu memberikan apersepsi dengan menghubungkan pengetahuan awal, atau pengetahuan yang sudah dimiliki siswa sebelum memasuki materi baru yang akan dipelajari. Sejalan dengan teori Ausubel yang menyatakan bahwa pengaktifan pengetahuan sebelumnya dapat meningkatkan pemahaman dan memori (bermakna) (Slavin, 2011).

\section{B. Hasil Belajar Kompetensi Keterampilan}

Penilaian hasil belajar aspek keterampilan siswa dilakukan dengan cara melakukan observasi pada kinerja siswa selama melakukan observasi dan praktik di laboratorium. Pengamatan dilakukan berdasarkan indikator yang dirumuskan dari KD 4 , kemudian di pecah ke dalam beberapa aspek keterampilan kinerja yang dapat teramati dan terukur, seperti terlihat pada Tabel 4 berikut. 
Tabel 4. Skor Keterampilan Siswa Pertemuan Pertama

\begin{tabular}{|l|c|c|}
\hline \multirow{2}{*}{ Indikator } & \multicolumn{2}{|c|}{ Nilai siswa } \\
\cline { 2 - 3 } & Terendah & Tertinggi \\
\hline $\begin{array}{l}\text { Melakukan observasi } \\
\text { terhadap sistem perairan } \\
\text { yang tercemar di } \\
\text { lingkungan sekitar. }\end{array}$ & 3,0 & 3,8 \\
\hline $\begin{array}{l}\text { Membuat tulisan tentang } \\
\text { gagasan penanggulangan } \\
\text { pencemaran air di } \\
\text { lingkungan sekitar. }\end{array}$ & 3,4 & (SB) \\
\hline
\end{tabular}

Keterangan: B: Baik, SB: Samgat baik.

Pada pertemuan pertama, terdapat dua indikator keterampilan yang di rumuskan, yang terkait dengan kinerja siswa selama melakukan observasi dan laporan hasil observasi dan tulisan siswa berupa gagasan usaha penanggulangan pencemaran air di lingkungan sekitar. Skor rata-rata yang diperoleh masing-masing siswa dari pengamatan terhadap kinerja siswa selama melakukan observasi adalah berkisar antara 3,0 - 3,8 dengan kategori baik dan sangat baik. Hal ini menunjukkan bahwa siswa sudah memiliki keterampilan dan dapat melakukan observasi dengan sangat baik. Observasi sangat bermanfaat bagi pemenuhan rasa ingin tahu siswa karena siswa yang terlibat dalam proses mengamati akan dapat menemukan fakta bahwa ada hubungan antara obyek yang dianalisis dengan materi pembelajaran yang digunakan oleh guru. Namun demikian, kekurangan dari observasi yang dilakukan siswa adalah terkait dengan aspek terakhir kegiatan siswa yaitu dalam hal mencari informasi tambahan tentang fungsi dan kondisi perairan yang diamati, kegiatan ini dilakukan siswa namun masih belum bisa dikatakan optimal, karena narasumber yang diwawancarai hanya dua orang warga sekitar yang berjualan di warung di lingkungan sekolah, sehingga informasi yang diperoleh dan dilaporkan siswa pun cenderung sama. Siswa tidak dapat melakukan wawancara lebih lanjut ke warga lainnya dikarenakan keterbatasan waktu dalam melakukan kegiatan ini. Basuki \& Hariyanto (2014) menyatakan bahwa pertimbangan dalam melakukan wawancara adalah waktu yang diperlukan cukup lama, terutama jika pewawancara tidak siap dengan pertanyaanpertanyaan yang memandu wawancara.
Indikator kedua yaitu terkait dengan laporan hasil observasi lingkungan perairan yang tercemar. Dari penilajan terhadap tugas berupa laporan yang dikumpulkan oleh siswa diperoleh skor rata-rata tiap siswa rogleitu berkisar dari 3,4 - 3,9 dengan kategori sangat baik3 Hal ini menunjukkan bahwa siswa sudah bisa fiembuat laporan dengan sangat baik dan memberikan saran penanggulangan pencemaran sestai dengan kondisi air tercemar yang diamati. Walaupun masih ada beberapa siswa yang kurang tepat dalam menuliskan kesimpulan, namun hal ini wajarSByengingat siswa sebelumnya belum pernah membuat laporan hasil pengamatan.

Pada pertemuan kedua terdapat tiga indikator yang menjadi dasar penilaian keterampilan siswa, yaitu terkait dengan keterampilan kinerja siswa saat melakukan praktik pengujian sifat air yang tercemar dan dalam membuat laporan hasil praktik, seperti terdapat pada Tabel 5 berikut.

Tabel 5. Skor Keterampilan Siswa Pertemuan Kedua

\begin{tabular}{|c|c|c|c|}
\hline \multirow{2}{*}{ Indikator } & \multicolumn{2}{|c|}{ Nilai siswa } & \multirow{2}{*}{$\begin{array}{c}\text { Rata- } \\
\text { rata }\end{array}$} \\
\hline & Terendah & Tertinggi & \\
\hline $\begin{array}{l}\text { Melakukan percobaan } \\
\text { untuk menguji sifat } \\
\text { air yang tercemar } \\
\text { menggunakan kertas } \\
\text { lakmus. }\end{array}$ & $\begin{array}{c}3,6 \\
\text { (SB) }\end{array}$ & $\begin{array}{c}4,0 \\
(\mathrm{SB})\end{array}$ & $\begin{array}{c}3,9 \\
(\mathrm{SB})\end{array}$ \\
\hline $\begin{array}{l}\text { Melakukan percobaan } \\
\text { untuk menguji sifat } \\
\text { air yang tercemar } \\
\text { menggunakan } \\
\text { indikator alami. }\end{array}$ & $\begin{array}{c}3,3 \\
(\mathrm{SB})\end{array}$ & $\begin{array}{c}4,0 \\
(\mathrm{SB})\end{array}$ & $\begin{array}{c}3,6 \\
\text { (SB) }\end{array}$ \\
\hline $\begin{array}{l}\text { Membuat laporan } \\
\text { hasil pengujian sifat } \\
\text { air yang tercemar } \\
\text { menggunakan } \\
\text { indikator asam-basa. }\end{array}$ & $\begin{array}{l}3,0 \\
\text { (B) }\end{array}$ & $\begin{array}{c}3,7 \\
(\mathrm{SB})\end{array}$ & $\begin{array}{c}3,5 \\
\text { (SB) }\end{array}$ \\
\hline
\end{tabular}

Keterangan: B:Baik, SB: Sangat baik.

Observasi pertama terkait dengan pengujian air tercemar menggunakan kertas lakmus. Skor rata-rata kinerja siswa pada pengujian menggunakan kertas lakmus adalah berkisar antara 3,6 - 4,0 dengan kategori sangat baik. Ini artinya siswa sudah memiliki keterampilan yang sangat baik dalam hal menggunakan kertas lakmus untuk mengetahui sifat air yang tercemar/sifat larutan. Hal ini karena sebelum melakukan kegiatan praktik, siswa diberikan pengetahuan cara pengujian yang benar melalui 
demonstrasi yang dilakukan oleh guru, siswa langsung mengamati langkah kerja yang dilakukan oleh guru. Sejalan dengan pendapat Bandura yang menyatakan bahwa banyak pembelajaran manusia dipelajari dengan lebih efisien langsung dari suatu model (Slavin, 2011).

Observasi selanjutnya pada pertemuan kedua adalah terkait pengujian air yang tercemar menggunakan indikator alami. Indikator alami yang digunakan adalah berupa larutan dari bunga sepatu dan kol ungu, yang sudah dibuat oleh guru bersama siswa sehari sebelum dilakukan praktik. Rata-rata skor yang diperoleh siswa yaitu berkisar antara 3,34,0 , yang menunjukkan bahwa siswa sudah memiliki keterampilan yang sangat baik dalam praktik pengujian sifat air yang tercemar menggunakan indikator alami. Adapun sedikit kekurangan yang ditemukan observer dalam praktik ini adalah, beberapa siswa masih belum tepat benar dalam hal menggunakan pipet tetes, hal ini dikarenakan siswa baru pertama kali menggunakan pipet tetes, sehingga banyak siswa yang merasa canggung dalam menggunakannya, apalagi mengingat pipet terbuat dari bahan kaca yang tipis dan rentan pecah.

Penilaian terakhir terkait dengan keterampilan siswa pada pertemuan kedua yaitu penilaian terhadap laporan hasil praktik pengujian sifat air yang tercemar. Skor rata-rata siswa yang dinilai dari laporan hasil praktik adalah berkisar antara 3,0-3,7 dengan kategori baik dan sangat baik. Hal ini menunjukkan bahwa siswa sudah memiliki keterampilan dalam hal menganalisis data hasil praktik menjadi sebuah laporan hasil praktik, meskipun dalam membuat analisis data siswa masih perlu dibantu dengan pertanyaan-pertanyaan untuk mengarah pada analisis data. Aspek yang diamati peneliti masih kurang dari laporan yang dibuat siswa adalah terkait aspek kesesuaian isi laporan dengan teori, yaitu beberapa siswa masih belum bisa mengkaitkan hasil pengamatan dengan teori pada materi yang mendukung.

Pertemuan ketiga pada penilaian keterampilan siswa dilakukan pada saat siswa melakukan praktik untuk mejernihkan air menggunakan metode pemisahan campuran, selain itu juga penilaian dari laporan hasil praktik penjernihan air yang dilakukan siswa, seperti terdapat pada Tabel 6 berikut.

Tabel 6. Skor Keterampilan Siswa Pertemuan Ketiga

\begin{tabular}{|l|c|c|c|}
\hline \multirow{2}{*}{\multicolumn{1}{|c|}{ Indikator }} & \multicolumn{2}{|c|}{ Nilai siswa } & Rata- \\
\cline { 2 - 3 } & Terendah & Tertinggi & rata \\
\hline $\begin{array}{l}\text { Melakukan percobaan } \\
\text { untuk menjernihkan } \\
\text { air menggunakan cara } \\
\text { filtrasi }\end{array}$ & 3,3 & 3,8 & 3,6 \\
$(\mathrm{SB})$ & $(\mathrm{SB})$ & $(\mathrm{SB})$ \\
\hline $\begin{array}{l}\text { Melakukan percobaan } \\
\text { untuk menjernihkan } \\
\text { air menggunakan cara }\end{array}$ & 3,3 & 3,6 & 3,5 \\
distilasi & $(\mathrm{SB})$ & $(\mathrm{SB})$ & $(\mathrm{SB})$ \\
\hline $\begin{array}{l}\text { Membuat laporan } \\
\text { hasil percobaan untuk } \\
\text { menjernihkan air } \\
\text { menggunakan metode } \\
\text { pemisahan campuran }\end{array}$ & 2,8 & 3,8 & 3,4 \\
\hline
\end{tabular}

Keterangan: B:sangat baik; SB: sangat baik.

Observasi pertama dilakukan pada saat siswa melakukan praktik penjernihan air menggunakan cara filtrasi. Skor rata-rata yang diperoleh tiap siswa dalam praktik pertama ini adalah berkisar antara 3,33,8 dengan kategori sangat baik. Hal ini menunjukkan bahwa siswa sudah memiliki keterampilan kinerja yang sangat baik dalam melakukan praktik filtrasi. Walaupun alat praktik yang digunakan tidaklah optimal, namun hal itu tidak mempengaruhi kegiatan praktik yang dilakukan siswa, hanya berpengaruh terhadap pengelolaan waktu. Kesuksesan siswa dalam melakukan percobaan filtrasi ini juga tidak lepas karena adanya kerjasama yang baik antarsiswa dalam kelompoknya, di mana siswa saling membantu dalam kegiatan eksperimen (Eggen \& Kauchak, 2013).

Observasi lainnya pada pertemuan ketiga yang terkait dengan keterampilan kinerja siswa yaitu diamati pada saat siswa melakukan praktik penjernihan air menggunakan metode distilasi dengan tenaga surya. Skor yang diperoleh masing-masing siswa dalam praktik kedua ini yaitu berkisar antara 3,3 - 3,6 dengan kategori sangat baik. Hal ini menunjukkan bahwa siswa sudah memiliki keterampilan kinerja yang sangat baik selama melakukan praktik. Beberapa kekurangan yang ditemukan oleh peneliti dalam hal kinerja siswa 
dalam memasang penutup bejana dan cara meletakan pemberat pada tutup bejana yang masih kurang tepat. Padahal ketepatan pemasangan penutup dan ketepatan letak pemberat pada tutup bejana sangat mempengaruhi hasil dari praktik distilasi yang dilakukan. Selain itu, distilasi sederhana menggunakan tenaga surya ini memerlukan waktu yang lama dalam hal pemanasannya, namun hal ini sedikit dapat teratasi karena siswa menggunakan bejana yang bentuknya luas, sehingga berpengaruh terhadap penguapan menjadi lebih cepat, selain itu, ada juga siswa yang menggunakan bejana yang terbuat dari logam sehingga panas yang sampai ke air juga lebih optimal. Akhirudin (2007) menyebutkan faktor-faktor yang berpengaruh terhadap produktivitas alat destilasi berbasis tenaga surya yaitu intensitas radiasi matahari, kecepatan angin serta lokasi geografis.

Penilaian selanjutnya pada keterampilan siswa yaitu penilaian laporan hasil praktik penjernihan air. Rata-rata skor tiap siswa yaitu berkisar antara 2,8 3,8 dengan kategori baik dan sangat baik. Hal ini menunjukkan bahwa siswa sudah memiliki keterampilan yang baik dalam melaporkan hasil pengamatan dalam praktik yang dilakukan. Namun demikian, kualitas dan skor rata-rata yang diperoleh siswa dari penilaian laporan hasil praktik pada pertemuan ketiga lebih rendah dibanding skor ratarata pada pertemuan kedua. Hal ini dikarenakan pada pertemuan ketiga, praktik yang dilakukan memerlukan waktu yang lebih lama dalam pengamatannya, dan karena waktu yang digunakan juga terbatas, hal itu berefek pada kualitas laporan yang dibuat oleh siswa, baik dalam hal isi yang kurang lengkap, dan kualitas penulisan serta bahasa dari laporan.

Rekapitulasi semua data hasil pengamatan keterampilan siswa pada ketiga pertemuan selanjutnya dianalisis dan dikonversi ke dalam bentuk angka (Dit. Pembinaan SMP, 2015), dan diperoleh nilai keseluruhan dari keterampilan siswa seperti terdapat pada Tabel 7.

Tabel 7. Hasil Belajar Kompetensi Keterampilan

\begin{tabular}{|c|c|c|c|c|}
\hline No. & $\begin{array}{c}\text { Inisial } \\
\text { Siswa }\end{array}$ & $\begin{array}{c}\text { Rata-rata } \\
\text { skor }\end{array}$ & Nilai & Kategori \\
\hline 1 & $\mathrm{C} 1$ & 3,5 & 87 & SB \\
\hline 2 & $\mathrm{C} 2$ & 3,4 & 84 & $\mathrm{~B}$ \\
\hline
\end{tabular}

\begin{tabular}{|c|c|c|c|c|}
\hline No. & $\begin{array}{c}\text { Inisial } \\
\text { Siswa }\end{array}$ & $\begin{array}{c}\text { Rata-rata } \\
\text { skor }\end{array}$ & Nilai & Kategori \\
\hline 3 & C3 & 3,5 & 87 & SB \\
\hline 4 & C4 & 3,4 & 84 & B \\
\hline 5 & C5 & 3,5 & 87 & SB \\
\hline 6 & C6 & 3,7 & 93 & SB \\
\hline 7 & C 7 & 3,6 & 90 & SB \\
\hline 8 & C 8 & 3,8 & 94 & SB \\
\hline 9 & C9 & 3,6 & 90 & SB \\
\hline 10 & C10 & 3,6 & 90 & SB \\
\hline 11 & C11 & 3,7 & 93 & SB \\
\hline 12 & C12 & 3,6 & 90 & SB \\
\hline 13 & C13 & 3,7 & 93 & SB \\
\hline 14 & C14 & 3,6 & 90 & SB \\
\hline 15 & C15 & 3,6 & 90 & SB \\
\hline 16 & C16 & 3,6 & 90 & SB \\
\hline 17 & C17 & 3,6 & 90 & SB \\
\hline 18 & C18 & 3,6 & 90 & SB \\
\hline 19 & C19 & 3,5 & 87 & SB \\
\hline 20 & C20 & 3,5 & 87 & SB \\
\hline 21 & C21 & 3,6 & 90 & SB \\
\hline 22 & C22 & 3,6 & 90 & SB \\
\hline 23 & C23 & 3,5 & 87 & SB \\
\hline 24 & C24 & 3,6 & 90 & SB \\
\hline \multicolumn{7}{|c|}{ Nilai Rata-Rata } & $\mathbf{8 9}$ & SB \\
\hline \multicolumn{7}{|l}{ Keterampilan Siswa } & & \\
\hline
\end{tabular}

Dari Tabel 7 dapat dilihat bahwa nilai rata-rata keterampilan siswa dapat dikategorikan sangat baik, dilihat dari nilai rata-rata kelas yaitu 89 , dengan nilai tertinggi 94 dengan kategori sangat baik dan nilai terendah 84 dengan kategori baik. Ini artinya siswa sudah memiliki keterampilan yang sangat baik dalam melakukan kegiatan praktik selama pembelajaran. Secara umum, siswa diamati tidak mengalami kesulitan dalam melakukan praktik dan menggunakan alat praktik. Hal ini karena sebelum siswa melakukan praktik, guru melakukan demonstrasi yang langsung diamati oleh siswa. Sejalan dengan pendapat Bandura yang menyatakan bahwa banyak pembelajaran manusia dipelajari dengan lebih efisien langsung dari suatu model (Slavin, 2011).

\section{PENUTUP}

Pembelajaran menggunakan perangkat pembelajaran IPA Terpadu tipe connected berpengaruh terhadap hasil belajar siswa SMP Negeri 2 Kelumpang Tengah dalam hal: (1) meningkatkan kompetensi pengetahuan siswa dengan skor $\mathrm{N}$-Gain berkategori tinggi; dan (2) mencapai ketuntasan indikator kompetensi keterampilan siswa yaitu 
dengan rata-rata kelas sebesar 89 atau berkategori sangat baik.

\section{DAFTAR PUSTAKA}

Akhirudin, Taufik. (2007). Desain Alat Destilasi Air Laut Berbasis Tenaga Surya Sebagai Alternatif Penyediaan Air Bersih. IPB: Skripsi.

Andansari, R. F. (2015). Penerapan Pembelajaran IPA Terpadu Tipe Connected Materi Sifat Larutan serta Keterkaitannya dengan Sumber Arus Listrik Kelas VII SMPN 1 Trawas Mojokerto. Jurnal Pendidikan Sains.

Basuki, Ismet \& Hariyanto. (2014). Asesmen Pembelajaran. Bandung: Rosda.

Depdiknas. (2006). Panduan Pengembangan Pembelajaran IPA Terpadu Sekolah Menengah Pertama/ Madrasah Tsanawiyah (SMP/MTs). http://www.puskur.net.

Eggen, Paul \& Kauchak, Don. (2013). Strategi dan Model Pembelajaran: Mengajarkan Materi dan Keterampilan Berpikir, Edisi 6 (Judul Asli: Strategie and Models for Teacher: Teaching Content and Thinking Skills, Sixth Edition, Alih Bahasa: Satrio Wahono). Jakarta: Indeks.

Hake, R.R. (1999). Analyzing Change/Gain Scores (http://www.physics.

indiana.edu/ sdi/AnalyzingChange-Gain.pdf diakses pada tanggal 15 Juni 2016).

Hamdayana, Jumanta. (2014). Model dan Metode Pembelajaran Kreatif dan Berkarakter. Bogor: Ghalia Indonesia.

Kemendikbud. (2013). Materi Pelatihan Guru Implementasi Kurikulum 2013. Jakarta: Kemendikbud.

Kemendikbud. 2015. Peraturan Menteri Pendidikan Dan Kebudayaan Republik Indonesia Nomor No 53 Tahun 2015 Tentang Panduan Penilaian Hasil Belajar Oleh Pendidik Pada Sekolah Menengah Pertama. Jakarta : Menteri Pendidikan Dan Kebudayaan Republik Indonesia.

Nisak, Khoirun. 2013. Pengembangan Perangkat Pembelajaran IPA Terpadu Tipe Connected pada Materi Pokok Sistem Ekskresi untuk Kelas IX SMP. Jurnal Pendidikan SainsPensa Vol. 01 No.1.

Peraturan Menteri Pendidikan dan Kebudayaan No.58 Tahun 2014. Tentang Kurikulum
2013 Sekolah Menengah Pertama/Madrasah Tsanawiyah. Jakarta: Depdikbud.

Schunk, Dale H. 2012. Teori-teori Pembelajaran. Yogyakarta: Pustaka Pelajar.

Slameto. 2010. Belajar dan Faktor-Faktor yang Mempengaruhi. Jakarta: PT Rineka Cipta.

Slavin, R. E. 2011. Psikologi Pendidikan Teori dan Praktik Edisi Kesembilan. Jakarta: PT. Indeks.

Wibowo, Widodo Setiyo. 2014. Pengembangan Kegiatan Pembelajaran IPA SMP Berbasis Scientific Approach dalam Konteks Kurikulum 2013 pada Topik Pemanasan Global. Makalah PPM "Workshop Penguatan Content Knowledge Keintegrasian Materi IPA SMP Kelas VII untuk Mengatasi Hambatan Guru IPA dalam Implementasi Kurikulum 2013" bagi Guru IPA SMP MGMP Sub Rayon 3 Kabupaten Magelang.

Peraturan Menteri Pendidikan dan Kebudayaan No.58 Tahun 2014. Tentang Kurikulum 2013 Sekolah Menengah Pertama/Madrasah Tsanawiyah. Jakarta: Depdikbud.

Schunk, Dale H. 2012. Teori-teori Pembelajaran. Yogyakarta: Pustaka Pelajar.

Slameto. 2010. Belajar dan Faktor-Faktor yang Mempengaruhi. Jakarta: PT Rineka Cipta.

Slavin, R. E. 2011. Psikologi Pendidikan Teori dan Praktik Edisi Kesembilan. Jakarta: PT. Indeks.

Wibowo, Widodo Setiyo. 2014. Pengembangan Kegiatan Pembelajaran IPA SMP Berbasis Scientific Approach dalam Konteks Kurikulum 2013 pada Topik Pemanasan Global. Makalah PPM "Workshop Penguatan Content Knowledge Keintegrasian Materi IPA SMP Kelas VII untuk Mengatasi Hambatan Guru IPA dalam Implementasi Kurikulum 2013" bagi Guru IPA SMP MGMP Sub Rayon 3 Kabupaten Magelang. 